\title{
Impacts of Monetary Policy on Stock Market through Survey from Investors
}

\author{
Trung Thanh Nguyen ${ }^{1 \& 2}$, Thi Linh Do ${ }^{3} \&$ Van Duy Nguyen ${ }^{4}$ \\ ${ }^{1}$ School of Economics, Shanghai University, Shanghai, China \\ ${ }^{2}$ Faculty of Economics and Business Administration, Hatay Community college, Hanoi, Vietnam \\ ${ }^{3}$ Faculty of Accounting and Finance, Hatay Community college, Hanoi, Vietnam \\ ${ }^{4}$ Vietnam Quantitative Analysis Join Stock Company, Hanoi, Vietnam \\ Correspondence: Trung Thanh Nguyen, School of Economics, Shanghai University, 99 Shangda Road, Baoshan \\ District, Shanghai 200444, China. E-mail: ngthanhhn@gmail.com
}

\author{
Received: April 13, $2016 \quad$ Accepted: May 7, $2016 \quad$ Online Published: May 23, 2016 \\ doi:10.5539/jms.v6n2p132 URL: http://dx.doi.org/10.5539/jms.v6n2p132
}

\begin{abstract}
Analyzing the impacts of the monetary policy on the stock market is very important to investors. There are many papers studying this relationship, but study based on investors is still limited. This paper is conducted by interviewing experts and Stock Investors in Vietnam. After having research results, the authors continue to use multi-variables method (EFA, regression analysis) and get the following outcomes: According to investors, the policy of interest rate, required reserved ration and exchange rate have impacts on Vietnam stock market; the policy of money supply does not have influence on the market. At the same time, interest rate has the strongest impact on stock market following by the required reserved ratio and the exchange rate.
\end{abstract}

Keywords: EFA, monetary policy, regression analysis, stock price

\section{Introduction}

Vietnam stock market was born in 2000 firstly in HCM city, but till 2005 the Stock center was established in Hanoi. Despite of being a newborn trading center, Vietnam Stock market has experienced in periods of both strong development and severe recession. From 2005-2008 the stock price reached a record height at 1137.69 points in Mar 12th 2007, then fell sharply to 245.74 point in Feb 24th 2009. Since this period, the market grows slowly with fluctuated level around 500 points (Vietstock, 2016).

Recently, there are tens of billions of transactions on the Stock Exchange daily in Vietnam. Profits from stocks are the main income for many young peoples or the accumulated pension of the old (Maskay, 2007). The change (degradation) of the stock market will impact on the turmoil in investors' lives because it directly relates to their main income. These changes are due to the impact of international market factors (Maskay, 2007) or the monetary policy (macroeconomic) of the state bank. Therefore; the study of impacts of policies especially monetary policy and information shock is considered as an important key which helps investors to make right decisions.

There have been many studies on fluctuation of the stock price and monetary policy. Most of them approved that stock indices react sensitively to changes of monetary policy (Zare, Azali, \& Habibullah, 2013). Stock Investors always keep their eyes on market's changes in general and the monetary policy of the state bank in particular in order that they can make a right decision which will bring benefit. Hence, studying impacts of factors on stock price become a vital part which helps investors to make investing decision.

In Vietnam, nowadays there are some studies on macroeconomics or the monetary policy (Ton \& Nguyen, 2015) however, most of them focused on studying and analyzing macro data. There is no study which really researches the impact of the monetary policy on the stock market through analyzing investor survey' result. Therefore; this report is proceeded to consider this relationship. 


\section{Method}

\subsection{Research Design}

Manners of interviewing experts and making the factors as well as giving the observed variables, which have impact on stock market prices in Vietnam, are below:

The first is interviewing directly experts, who are stock investors having one year of experience. The second is making a list of about 20 investors to serve the interview process. During the interview process, the authors collected the views of experts on interview aspects. They made interview and achieved the last information based on information saturation theory (Figure 1). By interviewing each person, the autor will get some general information compared to other professionals. Continuing interview until 3 consecutive people does not give new information compared to the previous ones, it is considered the point of saturation of information. Currently, they stopped interviewing and filtered the information obtained from the interviewees

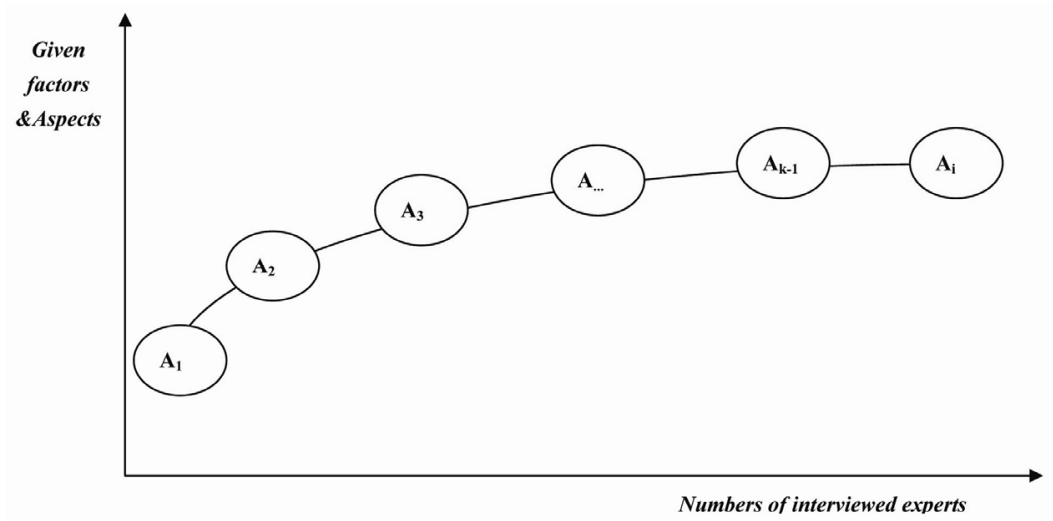

Figure 1. Interviewing expert methods

Once the interview finished, the authors proceeded to filter information obtained from experts and forming the same factors aspects (observed variables of each factor). They designed the preliminary questionnaire and performed a trial investigation in about 100 votes to review and edited the appropriate questionnaires to find out the interviewee's ability in the survey, as well as survey results of preliminary data analysis

After designing official questionnaires, the authors deliver about 200-500 survey notes to Vietnam Stock Investors (the research object).

\subsection{Sample Size}

Total studied samples are stock investors in Vietnam. However, within this title, studying all samples will be impossible. Therefore, the size of samples is selected towards the minimum rules to ensure reliability. For this research, the authors get sample of 200 according to the principle of Comrey \& Lee (1992).

\subsection{Data Collection Method}

The authors conducted survey forms directly from stock investors at Vietnam Stock Exchange market. After recovery of the questionnaire, the authors conducted encoding and put it into SPSS for analysis.

\subsection{Data Analysis}

\subsubsection{Assessment of Scale's Reliability}

The elements are formed from three or more different questions to ensure the initial conditions to create initially assumed factor. To check the reliability of this scale of factors, the authors used Cronbach`s Alpha coefficients to measure the synthesis confidence level (Suanders et al., 2007) and overall variable correlations to examine the relationship among indicators in each factor. Criteria for assessing a reliable scale in research is a minimum Cronbach`s Alpha ratio of 0.6 (Hoang \& Chu, 2008) and the overall variable correlation coefficient with a minimum of 0.3 (Nunnally \& Burstein, 1994). The results of the reliability of scale test from research data as following: 


\subsubsection{Factor Analysis}

After factors are analyzed by Cronbach's Alpha, the authors continue to put them into EFA test. According to Hair et al. (2006), analyzing factors will help researchers to draw significant potential factors from a set of smaller observed variables. Some standards are applied when analyzing EFA as follows: If KMO value is bigger than 0.5 , factor analysis is appropriate; whereas if the value $\mathrm{KMO}$ is less than 0.5 , factors analysis is not suitable with the data. Variance explained needs to be greater than $50 \%$ to ensure the change of observations. In order that scaling reaches assemblage value, according to Anderson \& Gerbing (1988), the correlation coefficient and factor loading needs to be bigger or equal to 0.5 in one factor. The method of principal components with rotated component is used to ensure the smallest amount of factors according to Hoang \& Chu (2008).

\subsubsection{Regression Analysis}

With factors which appeared after analyzing EFA, the authors conducted to put these factors into regression analysis to find out, among many tools of monetary policy, what is the kind of monetary policy indeed affects the stock market according to the Investors. The authors also review which the factors has stronger impact on the stock market through standardized beta coefficient.

\section{Results}

\subsection{Assessment of Scale's Reliability}

Basically, the assessment's result shows that all preliminary assessment results indicate the reliability of the scale factors with the coefficient Cronbach's alpha is greater than 0.6; total variable correlation coefficients are greater than 0.3. From this result, it clearly shows that the factors are designed with consistent internal scale (Table 1).

Table 1. Result of test the credibility of scale

\begin{tabular}{llll}
\hline Factor & Observed variables & Cronbach Alpha & $\begin{array}{l}\text { Corrected Item- } \\
\text { Total Correlation } \\
\text { correlation coefficient }\end{array}$ \\
& & & 0.665 \\
Interest rate policy & IR1 & 0.892 & 0.771 \\
& IR2 & & 0.766 \\
& IR3 & & 0.672 \\
& IR4 & & 0.681 \\
\hline Required reserve ratio & RR1 & 0.809 & 0.625 \\
& RR2 & & 0.600 \\
& RR3 & 0.732 & 0.567 \\
\hline Money supply & M1 & & 0.500 \\
\hline Exchange rate & M2 & 0.767 & 0.627 \\
& EX1 & & 0.616 \\
& EX2 & & 0.572 \\
\hline Impact of monetary policy & Y1 & 0.796 & 0.672 \\
on stock marktet & Y2 & & 0.676 \\
& Y3 & & 0.597 \\
\hline
\end{tabular}

Source: Result from SPSS and collection of the authors.

\subsection{Factor analysis}

\subsubsection{Analysis of Factors for Independent Variables}

Results which are from analyzing factors with 4 independent variables and waiving observed variables with factor floading of less than 0.5 can be shown as belows: 
Table 2. Result of test of the factor analysis for independent variable

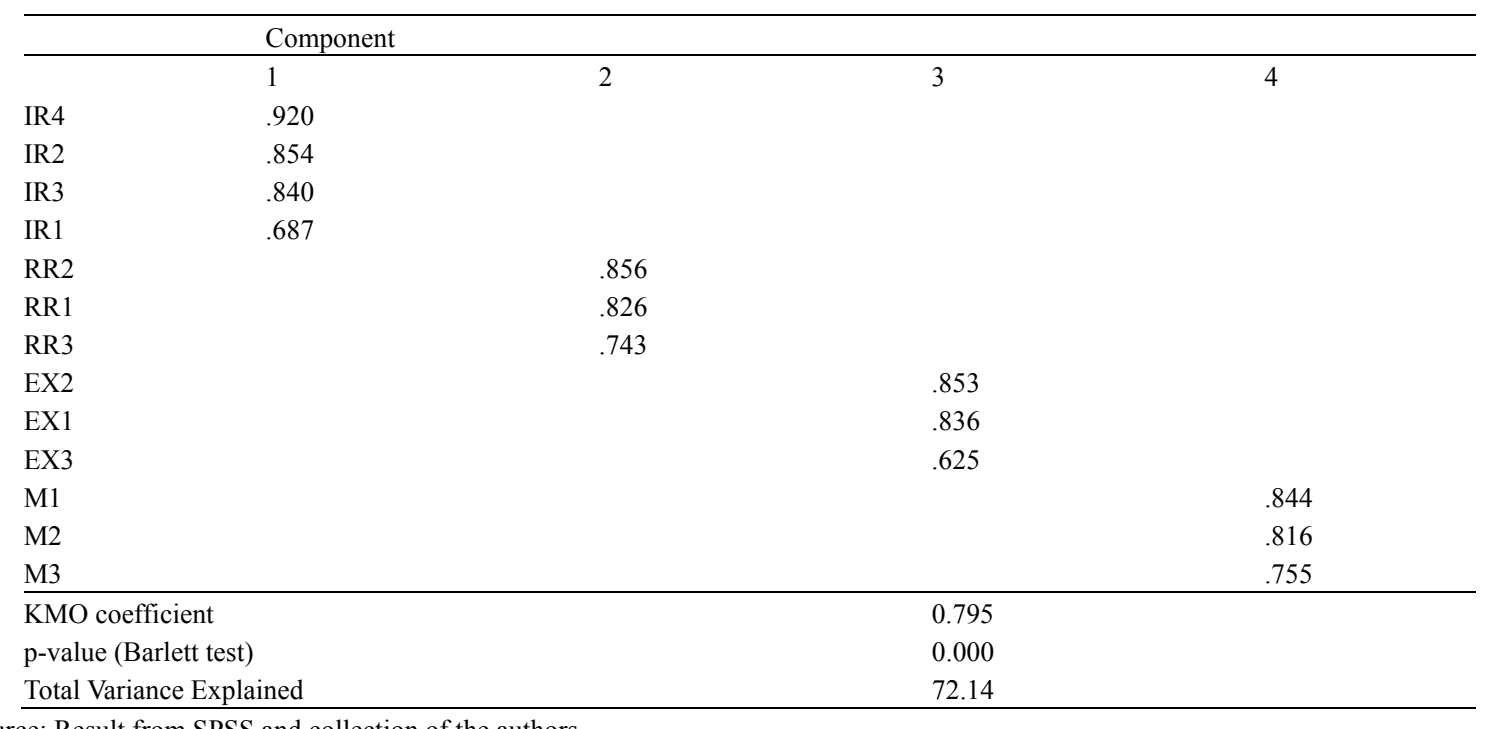

Source: Result from SPSS and collection of the authors.

The analysis results show in Table 2 that the KMO coefficient is 0.795 , more than 0.5 ; Batlett testing with p-value is 0.000 , less than 0.05 ; the Total Variance Explained is $72.14 \%$, more than $50 \%$; the loading factors are greater than 0.5; and the observed variables formed four factors. Thus, standards using factor analysis are consistent with research data

\subsubsection{Analysis of Factors for Dependent Variables}

In Table 3, The analysis results show that the KMO coefficient is 0.702 , more than 0.5; Batlett testing with p-value is 0.000 , less than 0.05 ; the variance is $71.46 \%$, more than $50 \%$; the loading factors are greater than 0.5 ; and the observed variables formed 1 factor. Thus, standards using factor analysis are consistent with research data collection.

Table 3. Result of test of the factor analysis for dependent variable

\begin{tabular}{ll}
\hline & Component \\
\hline & 1 \\
Y2 & .862 \\
Y1 & .860 \\
Y3 & .813 \\
\hline KMO coefficient & 0.702 \\
p-value (Barlett test) & 0.000 \\
Explained variance & $71.46 \%$ \\
\hline
\end{tabular}

After obtaining the explored factors, the authors evaluated relationships between factors through analysis of correlation and regression analysis.

\subsection{Correlation Analysis}

Results showed in the correlation tables are all related variables in the same direction (correlation coefficients are + ). In terms of the relationship to the dependent variable $\mathrm{Y}$ : IR variables most strongly correlated with the $\mathrm{Y}$ (0.697), followed by the variable RR (0.603) and the weakest variables correlated with Y: the variable $M(0.138)$. (Table 4), however, the correlation is not significant in the regression impact assessment (one-way) of the independent variables on the dependent variable. Therefore, to clarify the impact of monetary policy on the stock market, the authors conducted a regression analysis. 
Table 4. Relationship between pairs of variables

\begin{tabular}{|c|c|c|c|c|c|}
\hline & $\mathrm{Y}$ & IR & RR & $\mathrm{M}$ & EX \\
\hline $\mathrm{Y}$ & 1 & & & & \\
\hline IR & $.697 * *$ & 1 & & & \\
\hline RR & $.603 * *$ & $.484 * *$ & 1 & & \\
\hline M & $.138 *$ & .085 & .035 & 1 & \\
\hline EX & $.534 * *$ & $.478 * *$ & $.416^{* *}$ & .085 & 1 \\
\hline
\end{tabular}

**. Correlation is significant at the 0.01 level (2-tailed).

*. Correlation is significant at the 0.05 level (2-tailed).

Notes. Y: Assessing the impact of monetary policy on the Vietnam stock market; IR: Interest rate policy; RR: Required reserve ratio; M: Money supply; EX: Exchange rate.

\subsection{Regression Analysis}

Regression analysis indicates the impact of the independent variables on the dependent variables. In the independent initial hypothesis variables, there are some real independent variables having an impact on $\mathrm{Y}$ (p-value less than 0.05 regression analysis). For the variables with p-value larger than 0.05 , the authors will proceed to remove these excess variables from the model because there is no impact on the dependent variable $\mathrm{Y}$.

Initially, authors conducted to run regression with all variables under Enter method (taken at the same time all the variables in the model) and obtained the following results:

Table 5. Result of initial regression

\begin{tabular}{|c|c|c|c|c|c|c|c|}
\hline & & \multicolumn{2}{|c|}{ Unstandardized Coefficients } & \multicolumn{4}{|l|}{ Standardized } \\
\hline & & & & Coefficients & $-\mathrm{t}$ & $\mathrm{p}$-value & VIF \\
\hline & & $\mathrm{B}$ & Std. Error & Beta & & & \\
\hline \multirow{5}{*}{$\begin{array}{l}\text { Model } \\
\text { đầu }\end{array}$} & (Constant) & -.119 & .236 & & -.504 & .615 & \\
\hline & IR & .419 & .046 & .456 & 9.158 & .000 & 1.490 \\
\hline & ${ }^{n} \mathrm{RR}$ & .302 & .048 & .304 & 6.331 & .000 & 1.386 \\
\hline & $\mathrm{M}$ & .074 & .041 & .073 & 1.792 & .074 & 1.010 \\
\hline & EX & .184 & .048 & .184 & 3.841 & .000 & 1.379 \\
\hline \multicolumn{2}{|c|}{ Adjusted R2 } & 0.603 & & & & & \\
\hline \multirow{4}{*}{$\begin{array}{l}\text { Model } \\
\text { final }\end{array}$} & (Constant) & .106 & .200 & & .531 & .596 & \\
\hline & IR & .424 & .046 & .461 & 9.227 & .000 & 1.486 \\
\hline & $\mathrm{RR}$ & .301 & .048 & .302 & 6.267 & .000 & 1.386 \\
\hline & EX & .188 & .048 & .188 & 3.924 & .000 & 1.375 \\
\hline \multicolumn{2}{|c|}{ Adjusted R2 } & 0.599 & & & & & \\
\hline
\end{tabular}

\section{Regression equation}

$$
Y=0.106+0.424 * \text { Interest rate }+0.301 * \text { REQUIRED RESERVE RATIO }+0.188^{*} \text { Exchange rate }
$$

Adjusted R2 at 0.599 shows that model explains $59.90 \%$ change of stock market through monetary policy factors (Interest rate, required reserve ratio, Exchange rate).

With standardized beta coefficient indicates the impact of monetary policy factors on the stock market. The results show that interest rate policy has the strongest impact on the stock market $(0.461)$; next is required reserve ratio (0.302) and the exchange rate policy has the weakest impact on the stock market 


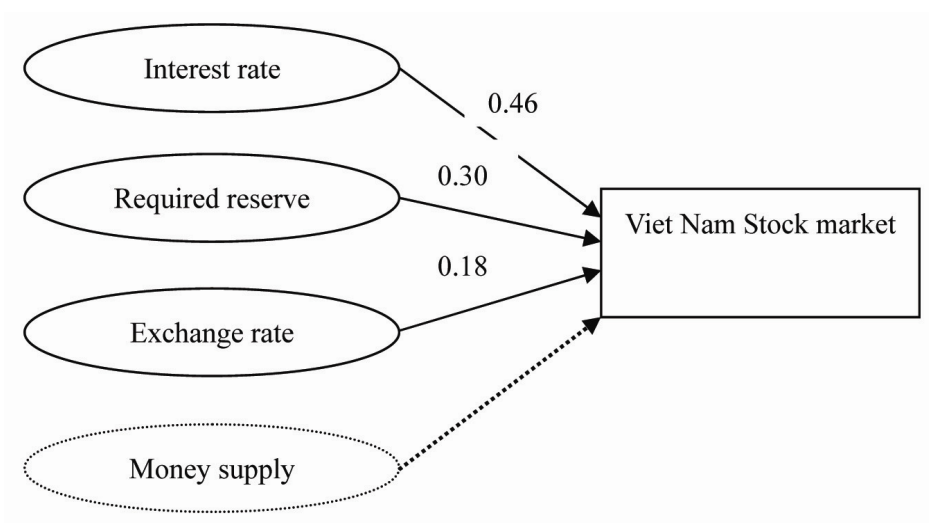

Figure 2. Result of regression analysis

\section{Discussion}

Interest rates have the opposite effect on the stock price. It shows that tightening the monetary (increasing interest rates) would make the stock market decrease. In the case of high inflation, state banks have tightened the monetary policy by raising interest rates, which in the short term will not affect the stock market, but in the long term will have negative affect to businesses, especially companies that use large amounts of bank loans for their business operations. The research results of interest rate is compatible with previous studies of Ali (2014); Dufour \& Tessier (2006); Okpara (2010); Fischbacher (2012); Zare et al. (2013) and Gali \& GAMBETTI (2013).

The policy of required reserve ratio also has the opposite effect on the stock price. Increasing the ratio of required reserve in banks limited the amount exchanged between banks and outside individual business. In the short time, companies can invest or make liquidity by external borrowings. However, in the longer term, increasing required reserve ratio will cause many difficulties for enterprises' business activities.

The exchange rate VND/USD has a negative impact on the stock price. It shows that adjusting exchange rate or currency devaluating will make stock market get worse. The reason comes from an increase in import price making difficulties for enterprises. It causes business activities in the country getting worse and stock price decreasing.

\section{Conclusion and Recommendations for Further Research}

Through analysing multi-variables data, the research result showed that policy factors impact on the stock price based on evaluation of investors (exchange rate, required reserve ratio policy have impact on Vietnam stock price, money suply has not impact on the stock price). Among them, interest rate policy has the most impact, next is required reserve ratio and exchange rate is the lowest. Money supply factor seems to have no impact on the stock price.

The study still exists some limits in the number of samples. Therefore, the authors propose that the following: study should extend sample size to support for the detailed and persuasive result. Besides, the authors would like to develop research method (coonfirm factor analysis-CFA) to measure the variables closely.

\section{Acknowledgments}

I would like to express my sincere gratitude to teachers in the Shanghai University who supported me a lot in the researching process. Also, I would like to thank you to the colleagues, classmates who help me in discussing and suggesting me enthusiastically to complete this research!

\section{References}

Ali, H. (2014). Impact of Interest Rate on Stock Market; Evidence from Pakistani Market. Journal of Business and Management, 16(1), 64-66.

Anderson, J. C., \& Gerbing, D. W. (1988). Structural Equation Modeling in Practice: A Review and Recommended Two-Step Approach. Psychological Bulleti, 103(3), 411-423. http://dx.doi.org/10.1037/0033-2909.103.3.411

Comrey, A. L., \& Lee, H. B. (1992). A first course in factor analysis. Hilsdale, New York, Erlbaun.

Dufour, J. M., \& Tessier, D. (2006). Short-Run and Long-Run Causality between Monetary Policy Variables and 
Stock Prices. Bank of Canada Working paper.

Fischbacher, U., Hen, T., \& Zeisberger, S. (2012). The impact of monetary policy on stock market bubbles and trading behavior: evidence from the lab. Journal of Economic Dynamics \& Control, 37(10), 2104-2122. http://dx.doi.org/10.1016/j.jedc.2013.04.004

Gali, J., \& Gambetti, L. (2013, 2014, 2015). The Effects of Monetary Policy on Stock Market Bubbles Some Evidence. Nber Working Paper Series.

Hair, J. F., Black, W. C., Babin, B. J., Anderson, R. E., \& Tatham, R. L. (2006). Multivariate Data Analysis (6th ed.). Upper Saddle River, NJ: Prentice-Hall.

Hoang, T., \& Chu, N. M. N. (2008). Analysis data with SPSS. Hong Kong: Publishing Hong Duc.

Maskay, B. (2007). Analyzing the Effect of Change in Money Supply on Stock Prices. The Park Place Economist, 15, 72-97.

Nunally, J. C., \& Bernstein, I. H. (1994). Psychometric Theory (3rd ed.). New York: McGraw-Hill.

Okpara, G. C. (2010). Monetary Policy and Stock Market Returns: Evidence from Nigeria. Journal Economic, $1(1), 13-21$.

Suanders, M., Lewis, P., \& Thornhill, A. (2007). Research method for business students. England: Pearson Education Limited, Edinburgh Gate, Harlow, Essex CM202 JE.

Ton Hoang, T. H., \& Nguyen, V. D. (2015). The Impact of The International Price Index on Vietnam Stock Market. International Conference on Emerging Challenges: Managing to Success, 1, 132-138.

Zare, R., Azali, M., \& Habibullah, M. S. (2013). Monetary Policy and Stock Market Volatility in the ASEAN5: Asymmetries over Bull and Bear Markets. International Conference on Economics and Business Research 2013, 18-27. http://dx.doi.org/10.1016/s2212-5671(13)00213-x

\section{Copyrights}

Copyright for this article is retained by the author(s), with first publication rights granted to the journal.

This is an open-access article distributed under the terms and conditions of the Creative Commons Attribution license (http://creativecommons.org/licenses/by/3.0/). 